\title{
Milk Yield, Reproduction and Milk Quality Characteristics of Simmental and Red-Holstein Cattle Raised at a Dairy Farm in Aydın Province: 2. Milk Quality
}

\author{
Atakan Koç ${ }^{1, a,{ }^{*}}$, Çă̆rı Arı ${ }^{2, b}$ \\ ${ }^{1}$ Department of Animal Science, Faculty of Agriculture, Aydin Adnan Menderes University, 09100 Aydin, Turkey \\ ${ }^{2}$ Alltech Biotechnology Gıda Tar. Hay. San. ve Dış Tic. Ltd. Şti. 35030 Bornova/İzmir, Turkey
}

*Corresponding author

\begin{tabular}{|c|c|}
\hline ARTICLE INFO & A B S T R A C T \\
\hline $\begin{array}{l}\text { Keywords: } \\
\text { Dairy cattle } \\
\text { Milk constituents } \\
\text { Raw milk quality }\end{array}$ & 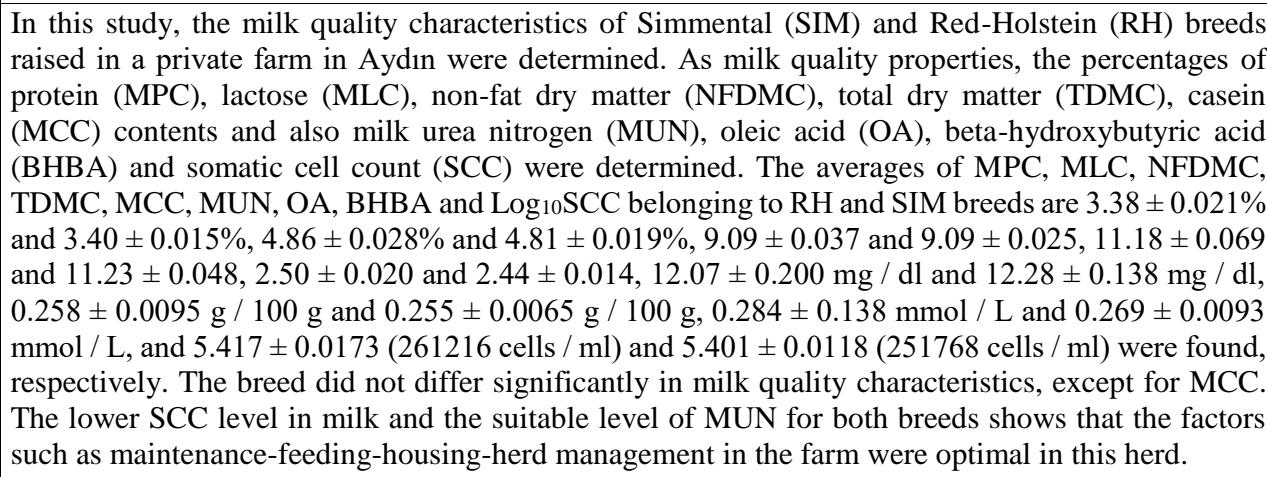 \\
\hline
\end{tabular}

Somatic cell count

Casein

Türk Tarım - Gıda Bilim ve Teknoloji Dergisi, 8(10): 2074-2080, 2020

\section{Aydın İlinde Bir Süt Sığırı İşletmesinde Yetiştirilen Simmental ve Kırmızı- Alaca Sığırların Süt ve Döl Verimi ile Süt Kalite Özellikleri: 2. Süt Kalitesi}

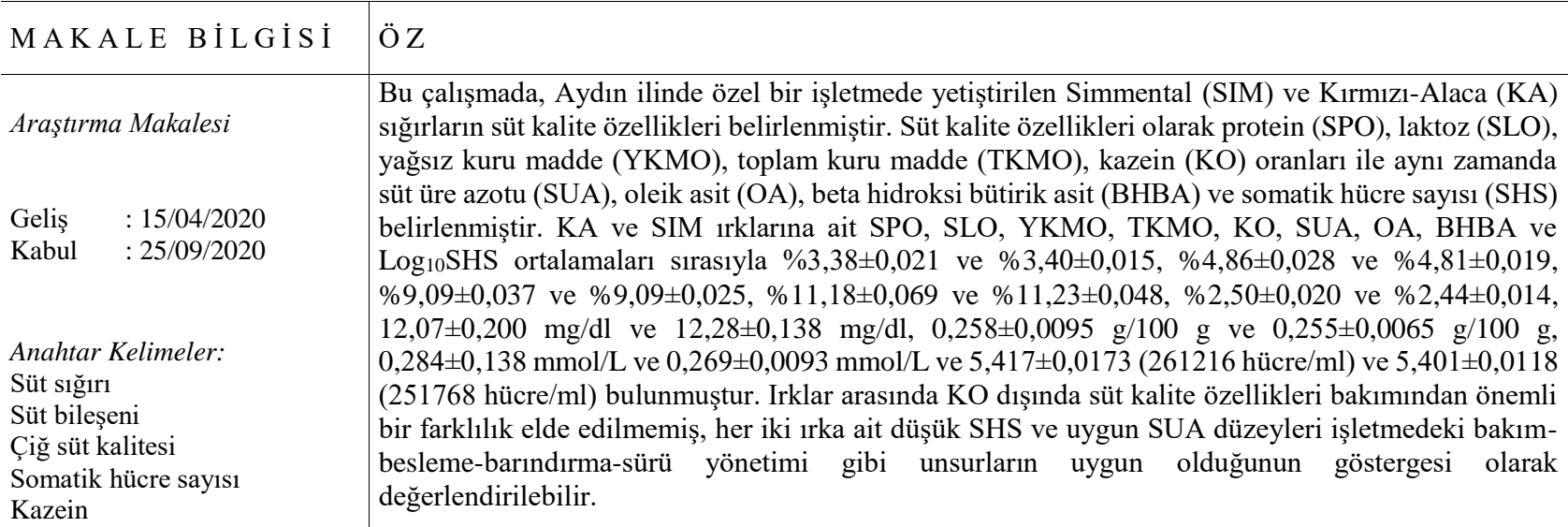




\section{Introduction}

It is estimated that approximately 150 million families worldwide are engaged in milk production. In developing countries, milk is produced and offered for sale by smallscale family farms, while it contributes to the family's basic livelihood, in developed countries it is produced by largescale enterprises that are large enough to support a family.

In recent years, in Turkey, the rise of red meat prices due to the lack of red meat production, and reproductive problems and low resistance to diseases in HolsteinFriesian (HF) that is the most common breed in the country have directed producers to rear Simmental (SIM) and RedHolstein (RH) breeds. SIM breed is one of the breeds that have come to be desired in recent years with its high milk yield and milk quality, high fattening performance, adaptation ability and docility (Koç, 2016). In recent years, another breed preferred as an alternative to HolsteinFriesian (HF) is RH.

Milk quality can be evaluated in two groups as the nutritional properties and hygienic properties of milk. While the nutritional quality of milk includes fat (MFC), protein (MPC), lactose (MLC), mineral substances, when the hygienic quality is mentioned, the number of total bacteria, somatic cell count (SCC) and antibiotic residue in milk are considered.

There are several results reported in the literature, for milk components of SIM breed by Akbulut (1998), Şekerden et al. (1999), Polanski et al. (1992). For HF and the Montbeliarde (MB) breed also known as French SIM (Koç et al., 2009) and Koç (2009; 2011), for HF and Brown-Swiss (Koç, 2007a), for HF breed (Koç, 2008) some values are reported. While Yılmaz (2010) and Koç (2015) reported some results for the milk components of RH, Yörükoğlu (2019) mentioned some results regarding the composition and quality of cattle milk coming to milk processing plants. Şekerden et al. (1999) reported the casein content (MCC) for SIM breed is $2.7 \pm 0.27 \%$.

By using the devices developed to analyze the ingredients in milk in more detail, the milk urea nitrogen (MUN), freezing point (FP), oleic acid (OA), betahydroxybutyric acid (BHBA) and raw milk pH have begun to be determined.

Mucha and Strandberg (2011) and Spek et al. (2016) focused on MUN, Vučić et al. (2012) stating that OA has many beneficial effects on human health, and milk and dairy products contain different amounts of OA and reported that there was a significant amount of OA in cow's milk (22.94-25.57\% of total fatty acid).

The cattle raw milk FP varies between -0.53 and $0.55^{\circ} \mathrm{C}$. If water is added to the milk, FP rises and becomes closer to zero. It is stated that FP of the milk is fixed as $0.555^{\circ} \mathrm{C}$ and the melt substances in milk decrease the FP of milk and it has been stated that FP of milk can be used to reveal the tricks made in milk (Anonymous, 2019a).

It has been stated that raw cattle milk has a slightly acidic $\mathrm{pH}$ and its $\mathrm{pH}$ value varies between 6.6 and 6.8. It is mentioned that the presence of phosphoric and stearic anions, especially casein, is caused by this slightly acidic reaction in milk. The acidity of milk is affected by lactation period, feeding, and the chemical composition of milk and, is stated that $36 \%$ of the acidic property of fresh milk is due to casein, $54-59 \%$ is from phosphates, $8-15 \%$ is from carbon dioxide, $8 \%$ is from album, $8 \%$ is due to citrates (Anonymous, 2019a). In addition, it was emphasized that the microorganisms found in milk break down lactose and cause the formation of lactic acid and some other acids, and this acidity is a subsequent acidity of milk (Anonymous, 2019a).

Taytak (2019) stated that urea, which is found in blood and body fluids as a small organic molecule, consists of carbon, nitrogen, oxygen and hydrogen, is also found in milk, and MUN is used as a biological indicator in proteinbased diets of dairy cattle. In addition to being a tool for determining the source of the reproductive problem in dairy cattle, MUN is also used to evaluate whether the diets energy-protein balance is appropriate. MUN in the milk of a normal cow is $7-12 \mathrm{mg} / \mathrm{dl}$. It was mentioned that if the MUN value was above $12 \mathrm{mg} / \mathrm{dl}$, the ration protein content was high, and the MUN value was $<5 \mathrm{mg} / \mathrm{dl}$, the ration protein content was not sufficient and there was not enough protein for the bacteria in the rumen (Anonymous, 2019b).

In a study, Taytak (2019) determined the levels of MUN, BHBA and acetone in the milk samples collected from 100 different dairy farms, and stated that acetone and BHBA values are the most important parameters used in the determination of metabolic diseases such as ketosis and fatty liver syndrome in lactating cows.

SCC provides information about udder health as well as being a raw milk quality criterion. In cases where SCC is over 200000 cells / $\mathrm{ml}$, the cow's udder is considered to have mastitis (Dohoo and Leslie, 1991).

Regarding SCC content in milk for HF breed, Koç (2006) and Atasever et al. (2018; 2020), for MB and HF breeds, Koç (2007b; 2011), on the farm basis SCC level Koç et al. (2009), for RH, Yılmaz (2010) and Koç (2015) and, also Yörükoğlu (2019) reported some results regarding the SCC level of cattle milk coming to milk processing plants. In SIM breed, there are no studies reported in our country regarding SCC level.

In this study, it was aimed to determine the milk quality characteristics of RH and SIM breeds raised together in a private dairy cattle farm in Aydin, Turkey. Detailed information about the performances of these breeds will be obtained, since there has not been any previous study or sufficient work on RH breed brought from Holland and SIM breed from Austrian SIM, which has been brought to our country in the last few years.

\section{Materials and Methods}

This study was carried out on SIM and RH breeds raised in a dairy cattle farm established in 2010 in Aydin, Incirliova Town, Sinırteke District. Milk components and SCC in milk were determined from milk samples taken from lactating animals in winter and summer seasons in 2018. The milk yield produced by the cows at the time of milk sampling was determined and it is accepted as the inspection time milk yield (ITMY). The milk samples were taken into sterile sample containers of $50 \mathrm{ml}$ milk from each animal, approximately equal to each teat, after the first 2-3 squeezed milk was milked to the ground before milking, and then carried it to a special milk analysis laboratory in the cold chain in Söke District, Aydın. The samples were analyzed for milk components by DairySpec 
FT (Bentley-Merkim Analytical Instruments). The samples were still preserved in the cold chain for SCC analysis done according to the Direct Microscopic Somatic Cell Count Method by bringing them to the ADU Faculty of Agriculture, Animal Science and Animal Breeding Laboratory.

Belonging to RH and SIM breeds, 94 and 204 milk samples were taken, respectively. In winter, 100 samples, in summer 198 samples were taken. By analyzing these samples, MFC (\%), MPC (\%), MCC (\%), MLC (\%), nonfat dry matter (NFDMC, \%), total dry matter (TDMC, \%), FP $\left({ }^{\circ} \mathrm{C}\right), \operatorname{MUN}(\mathrm{mg} / \mathrm{dL}), \mathrm{OA}$ (g / 100) g), BHBA (mmol / $\mathrm{L}), \mathrm{pH}$ and $\mathrm{SCC}$ (cell / $\mathrm{ml}$ ) were determined.

\section{Statistical Analysis}

In the statistical analysis of the data, it was made in the SAS (1999) package program, and the differences between the subgroups were determined according to Tukey $(\mathrm{P}<0.05)$ multiple comparison test results.

The following model was used in the statistical analysis of ITMY, MFC, MPC, MCC, MLC, NFDMC, TDMC, MUN, FP, OA, BHBA, milk pH and SCC values obtained from the milk samples taken before milking from lactating animals. Due to the high distribution of SCC data, logarithmic transformation was performed according to Log10 base before statistical analysis. The models used in the statistical analysis of the data are given below.

$$
\mathrm{y}_{\mathrm{ijk} k \mathrm{~m}}=\mu+\mathrm{a}_{\mathrm{i}}+\mathrm{b}_{\mathrm{j}}+\mathrm{c}_{\mathrm{k}}+\mathrm{d}_{1}+\left(\mathrm{ab}_{\mathrm{ij}}\right)+\left(\mathrm{ac}_{\mathrm{ik}}\right)+\left(\mathrm{bc}_{\mathrm{jk}}\right)+\left(\mathrm{ad}_{\mathrm{il}}\right)+\mathrm{e}_{\mathrm{ijklm}}
$$

Where;

$$
\begin{array}{ll}
\mathrm{y}_{\mathrm{ijklm}}: \text { Observed value of the trait } \\
\mu & : \text { Mean } \\
\mathrm{a}_{\mathrm{i}} & : \text { Breed effects }(\mathrm{i}=\mathrm{RH} \text { and SIM }) \\
\mathrm{b}_{\mathrm{j}} & : \text { Season effects }(\mathrm{j}=\text { winter, summer }) \\
\mathrm{c}_{\mathrm{k}} & : \text { Parity effects }(\mathrm{k}=1,2,3,4 \text { and } 5+) \\
\mathrm{d}_{\mathrm{l}} & : \text { Lactation period effects }(\mathrm{l}=1(4-100 \text { days }), 2 \\
& (101-200 \text { days) and } 3(>200 \text { days }))
\end{array}
$$

$(\mathrm{ab})_{\mathrm{ij}}$ : Breed- season interaction effects

(ac) $)_{\mathrm{ik}}$ : Breed-parity interaction effects

$(\mathrm{bc})_{\mathrm{jk}}$ : Season- parity interaction effects

$(\mathrm{ad})_{\mathrm{il}}$ : Breed- lactation period interaction effects

$\mathrm{e}_{\mathrm{ijklm}}$ : Random error.

\section{Results and Discussion}

The averages of the milk components for SIM and RH breeds are given in Table 1. The overall ITMY, MFC, MPC, MCC, MLC, NFDMC and TDMC means were calculated as $12.80 \pm 0.163 \mathrm{~kg}, 2.14 \pm 0.029 \%, 3.39 \pm$ $0.010 \%, 2.46 \pm 0.001 \%, 4.82 \pm 0.013 \%, 9.07 \pm 0.017 \%$ and $11.21 \pm 0.032 \%$, respectively. The ITMY mean was found $13.99 \pm 0.228 \mathrm{~kg}$ and $12.35 \pm 0.157 \mathrm{~kg}$ in $\mathrm{RH}$ and $\mathrm{SIM}$ breeds, respectively, about $1.65 \mathrm{~kg}$ difference between the breeds was determined $(\mathrm{P}<0.01)$.

In this study, the averages of ITMY calculated for RH and SIM breeds $(13.99 \pm 0.228 \mathrm{~kg}$ and $12.35 \pm 0.157 \mathrm{~kg}$, respectively) are higher than the yield reported for $\mathrm{RH}$ $(11.38 \pm 0.279 \mathrm{~kg})$ by Yilmaz (2010), for morning milk yield reported for HF $(9.75 \pm 0.392 \mathrm{~kg})$ and $\mathrm{MB}(7.69 \pm 0.274$ $\mathrm{kg}$ ) breeds by Koç (2011) and higher than the milk yield of morning $(11.63 \pm 0.217 \mathrm{~kg})$ and evening $(10.23 \pm 0.212 \mathrm{~kg})$ milkings for RH by Koç (2015).
The effects of season $(\mathrm{P}<0.01)$, lactation period $(\mathrm{P}<0.01)$, breed $x$ season $(\mathrm{P}<0.01)$, breed $\mathrm{x}$ parity $(\mathrm{P}<0.01)$, season $\mathrm{x}$ parity $(\mathrm{P}<0.01)$ and breed $\mathrm{x}$ lactation period $(\mathrm{P}<0.01)$ interaction effects on ITMY were found to be statistically significant, however, parity effect was not significant $(\mathrm{P}>0.05)$.

ITMY $(13.82 \pm 0.234 \mathrm{~kg})$ in winter is $1.3 \mathrm{~kg}$ higher than the time of milk sampling $(12.52 \pm 0.174 \mathrm{~kg})$ in summer $(\mathrm{P}<0.01)$. It can be said that the high air temperature seen in summer in the region affects the animals, resulting in heat stress in animal and as a result of that a decrease in feed consumption and accordingly a decrease in milk yield was seen. ITMY decreased significantly as expected according to the beginning, middle and end of the lactation period and was calculated as $14.85 \pm 0.188 \mathrm{~kg}, 13.67 \pm$ $0.247 \mathrm{~kg}$ and $11.00 \pm 0.273 \mathrm{~kg}$, respectively, and the differences between all periods were found to be statistically significant $(\mathrm{P}<0.01)$.

While the milk fat is low at the beginning of milking, it rises towards the end of milking. Since milk samples were taken before milking in this study, the samples will not represent the whole milking, so no discussion was made about MFC.

The interaction effects of breed $\mathrm{x}$ season on MPC was statistically significant $(\mathrm{P}<0.05)$, however, breed, sampling season, parity, lactation period, breed $\mathrm{x}$ parity, season $\mathrm{x}$ parity and breed $x$ lactation period interaction effects were not significant $(\mathrm{P}>0.05)$. MPC averages were calculated as $3.38 \pm 0.021$ and $3.40 \pm 0.015$ in RH and SIM breeds, respectively. MPC in the milk produced by the animals in summer $(3.38 \pm 0.01)$ was lower than the milk produced in winter $(3.40 \pm 0.022)$, but the difference between the seasons is not significant $(\mathrm{P}>0.05)$. In this study, the general average for MPC $(3.39 \% \pm 0.010)$ is higher than the average reported by Yörükoğlu (2019). MPC (3.40\% \pm $0.015 \%$ ) found for the SIM breed is lower than the average reported by Şekerden et al. (1999), however, is similar to the season and lactation averages reported by Polanski et al. (1992) and higher than the averages reported by Koç (2011) for MB and HF breeds. In this study, the average MPC for RH breed $(3.38 \% \pm 0.021)$ is also higher than the value reported by Y1lmaz (2010) for RH and the means of MB and HF breeds reported by Koç (2011).

In the milk samples taken in this study, MCC in milk was also determined. Casein is one of the milk proteins and is the most abundant protein in the milk. In this study, only the breed effect was found to be statistically significant on MCC $(\mathrm{P}<0.05)$, and the effects of other factors on MCC were not significant $(\mathrm{P}>0.05)$. MCC of $\mathrm{RH}(2.50 \pm$ $0.020 \%)$ was higher $(\mathrm{P}<0.05)$ than SIM breed $(2.44 \pm$ $0.014 \%$ ) (Table 1). In this study, MCC obtained for SIM and $\mathrm{RH}$ breeds were lower than the value reported for the SIM breed $(2.7 \pm 0.27 \%)$ by Şekerden et al. (1999).

Only breed $x$ parity interaction effect on MLC was found to be statistically important $(\mathrm{P}<0.01)$. The mean MLC of RH and SIM breeds were calculated as $4.86 \pm$ $0.028 \%$ and $4.81 \pm 0.019 \%$, respectively. In this study, MLC averages determined for both breeds were higher than the results found for MB and HF breeds by Koç et al. (2009) and Koç (2011) and RH breed reported by Yilmaz (2010). Also, the overall mean calculated for MLC (4.82\% $\pm 0.013)$ in this study is higher than the average reported by Yörükoğlu (2019). 
Parity and lactation period effects on NFDMC were found to be statistically significant $(\mathrm{P}<0.05)$. NFDMC mean of RH and SIM breeds were $9.09 \pm 0.037 \%$ and 9.09 $\pm 0.025 \%$, respectively. While NFDMC was calculated as $9.14 \pm 0.030 \%$ at the beginning of lactation, $9.02 \pm 0.040 \%$ at the middle and $9.12 \pm 0.044 \%$ at the end, NFDMC of the middle of lactation was different from the beginning of lactation $(\mathrm{P}<0.05)$. In this study, the overall mean calculated for NFDMC $(9.07 \pm 0.017 \%)$ is higher than the average reported by Yörükoğlu (2019).

NFDMC averages obtained for RH and SIM breeds are higher than the mean reported for SIM by Şekerden et al. (1999), for HF and MB breeds reported by Koç (2009;
2011), for RH reported by Yilmaz (2010). However, the means of NFDMC found for RH and SIM breeds in this study are lower than the values reported by Koç (2007a) and Koç (2008) for HF breed. The effects of all factors on TDMC were statistically insignificant $(\mathrm{P}>0.05)$. The averages of TDMC in RH and SIM breeds are $11.18 \pm$ 0.069 and $11.23 \pm 0.048$, respectively. In this study, TDMC obtained for RH and SIM breeds are lower than the means found for SIM by Şekerden et al. (1999) and for HF and MB breeds reported by Koç (2011). Again, in this study, the overall mean for TDMC $(11.21 \pm 0.032 \%)$ is lower than the average reported by Yörükoğlu (2019).

Table 1. Means and standard errors of inspection time milk yield (ITMY), fat (MFC), protein (MPC), casein (MCC), lactose (MLC), non-fat dry matter (NFDMC) and total dry matter (TDMC) contents

\begin{tabular}{|c|c|c|c|c|}
\hline Factor & $\bar{n}$ & ITMY kg & $\mathrm{MFC} \%$ & MPC \% \\
\hline Breed & & *** & NS & NS \\
\hline RH & 94 & $13.99 \pm 0.228^{\mathrm{Aa}}$ & $2.09 \pm 0.062$ & $3.38 \pm 0.021$ \\
\hline SIM & 204 & $12.35 \pm 0.157^{\mathrm{Bb}}$ & $2.14 \pm 0.043$ & $3.40 \pm 0.015$ \\
\hline Season & & $* *$ & NS & NS \\
\hline Winter & 100 & $13.82 \pm 0.234^{\mathrm{Aa}}$ & $2.07 \pm 0.64$ & $3.40 \pm 0.022$ \\
\hline Summer & 198 & $12.52 \pm 0.174^{\mathrm{Bb}}$ & $2.16 \pm 0.48$ & $3.38 \pm 0.016$ \\
\hline Parity & & NS & NS & NS \\
\hline 1 & 84 & $13.14 \pm 0.240$ & $2.03 \pm 0.066$ & $3.357 \pm 0.022$ \\
\hline 2 & 63 & $13.09 \pm 0.265$ & $2.10 \pm 0.073$ & $3.376 \pm 0.025$ \\
\hline 3 & 44 & $13.56 \pm 0.297$ & $2.11 \pm 0.081$ & $3.365 \pm 0.028$ \\
\hline 4 & 31 & $13.56 \pm 0.413$ & $2.19 \pm 0.113$ & $3.415 \pm 0.039$ \\
\hline $5+$ & 76 & $12.50 \pm 0.283$ & $2.16 \pm 0.078$ & $3.433 \pm 0.027$ \\
\hline Lac. Period & & $* *$ & NS & NS \\
\hline 1 (4-100 days) & 127 & $14.85 \pm 0.188^{\mathrm{Aa}}$ & $2.11 \pm 0.052$ & $3.40 \pm 0.018$ \\
\hline 2 (101-200 days) & 72 & $13.67 \pm 0.247^{\mathrm{Bb}}$ & $2.11 \pm 0.068$ & $3.36 \pm 0.023$ \\
\hline 3 (>200 days) & 99 & $11.00 \pm 0.273^{\mathrm{Cc}}$ & $2.13 \pm 0.075$ & $3.41 \pm 0.026$ \\
\hline Breed x Season & 298 & $* *$ & NS & $*$ \\
\hline Breed x Parity & 298 & $* *$ & NS & NS \\
\hline Season x Parity & 298 & $* *$ & $\mathrm{NS}$ & $\mathrm{NS}$ \\
\hline Breed x Lac. Period & 298 & $* *$ & NS & NS \\
\hline Overall & 298 & $12.80 \pm 0.163$ & $2.14 \pm 0.029$ & $3.39 \pm 0.010$ \\
\hline Factor & $\mathrm{MCC} \%$ & MLC \% & NFDMC \% & TDMC \% \\
\hline Breed & $*$ & NS & NS & NS \\
\hline RH & $2.50 \pm 0.020^{\mathrm{a}}$ & $4.86 \pm 0.028$ & $9.09 \pm 0.037$ & $11.18 \pm 0.069$ \\
\hline SIM & $2.44 \pm 0.014^{\mathrm{b}}$ & $4.81 \pm 0.019$ & $9.09 \pm 0.025$ & $11.23 \pm 0.048$ \\
\hline Season & NS & NS & NS & NS \\
\hline Winter & $2.48 \pm 0.0214$ & $4.85 \pm 0.029$ & $9.12 \pm 0.038$ & $11.20 \pm 0.071$ \\
\hline Summer & $2.47 \pm 0.0159$ & $4.82 \pm 0.021$ & $9.06 \pm 0.029$ & $11.22 \pm 0.053$ \\
\hline Parity & NS & NS & $*$ & NS \\
\hline 1 & $2.45 \pm 0.0219$ & $4.82 \pm 0.029$ & $9.03 \pm 0.038^{\mathrm{ab}}$ & $11.07 \pm 0.072$ \\
\hline 2 & $2.44 \pm 0.0242$ & $4.79 \pm 0.032$ & $9.98 \pm 0.042^{\mathrm{a}}$ & $11.08 \pm 0.080$ \\
\hline 3 & $2.48 \pm 0.0271$ & $4.92 \pm 0.036$ & $9.16 \pm 0.048^{b}$ & $11.26 \pm 0.089$ \\
\hline 4 & $2.52 \pm 0.0378$ & $4.84 \pm 0.051$ & $9.16 \pm 0.066^{\mathrm{ab}}$ & $11.36 \pm 0.013$ \\
\hline $5+$ & $2.48 \pm 0.0259$ & $4.81 \pm 0.035$ & $9.12 \pm 0.045^{\mathrm{ab}}$ & $11.28 \pm 0.086$ \\
\hline Lac. Period & NS & NS & $*$ & NS \\
\hline 1 (4-100 days) & $2.48 \pm 0.0171$ & $4.86 \pm 0.023$ & $9.14 \pm 0.030^{\mathrm{a}}$ & $11.26 \pm 0.057$ \\
\hline 2 (101-200 days) & $2.47 \pm 0.0225$ & $4.79 \pm 0.030$ & $9.02 \pm 0.040^{\mathrm{b}}$ & $11.13 \pm 0.074$ \\
\hline 3 (>200 days) & $2.47 \pm 0.0250$ & $4.86 \pm 0.034$ & $9.12 \pm 0.044^{\mathrm{ab}}$ & $11.25 \pm 0.083$ \\
\hline Breed x Season & $\mathrm{NS}$ & NS & $\mathrm{NS}$ & $\mathrm{NS}$ \\
\hline Breed x Parity & NS & $* *$ & NS & NS \\
\hline Season x Parity & NS & NS & NS & NS \\
\hline Breed x Lac. Period & NS & NS & NS & $\mathrm{NS}$ \\
\hline Overall & $2.46 \pm 0.001$ & $4.82 \pm 0.013$ & $9.07 \pm 0.017$ & $11.21 \pm 0.032$ \\
\hline
\end{tabular}

RH: Red-Holstein, SIM: Simmental, NS: Not significant, *: Significant for P<0.05, **: Significant for P<0.01, a,b,c: The difference between the groups with the same letter is insignificant for $\mathrm{P}<0.05$. A, B, C: The difference between the groups with the same letter is insignificant for $\mathrm{P}<0.01$. 
Table 2. Means and standard errors of milk urea nitrogen (MUN), freezing point (FP), oleic acid (OA), betahydroksybutyric acid (BHBA), $\mathrm{pH}$ and somatic cell count $\left(\log _{10} \mathrm{SCC}\right)$

\begin{tabular}{|c|c|c|c|c|}
\hline Factor & $\mathrm{n}$ & $\begin{array}{c}\text { MUN } \\
(\mathrm{mg} / \mathrm{dL})\end{array}$ & $\begin{array}{l}\text { FP } \\
\left({ }^{\circ} \mathrm{C}\right)\end{array}$ & $\begin{array}{c}\text { OA } \\
(\mathrm{g} / 100 \mathrm{~g})\end{array}$ \\
\hline Breed & & NS & NS & NS \\
\hline RH & 94 & $12.07 \pm 0.200$ & $-0.577 \pm 0.0012$ & $0.258 \pm 0.0095$ \\
\hline SIM & 204 & $12.28 \pm 0.138$ & $-0.579 \pm 0.0009$ & $0.255 \pm 0.0065$ \\
\hline Season & & NS & NS & NS \\
\hline Winter & 100 & $12.07 \pm 0.206$ & $-0.577 \pm 0.0013$ & $0.257 \pm 0.0097$ \\
\hline Summer & 198 & $12.28 \pm 0.153$ & $-0.579 \pm 0.0010$ & $0.256 \pm 0.0072$ \\
\hline Parity & & NS & NS & NS \\
\hline 1 & 84 & $12.13 \pm 0.210$ & $-0.581 \pm 0.0013$ & $0.255 \pm 0.0099$ \\
\hline 2 & 63 & $11.84 \pm 0.232$ & $-0.581 \pm 0.0015$ & $0.251 \pm 0.0110$ \\
\hline 3 & 44 & $12.36 \pm 0.261$ & $-0.576 \pm 0.0016$ & $0.239 \pm 0.0123$ \\
\hline 4 & 31 & $12.28 \pm 0.363$ & $-0.572 \pm 0.0023$ & $0.296 \pm 0.0172$ \\
\hline $5+$ & 76 & $12.70 \pm 0.249$ & $-0.579 \pm 0.0016$ & $0.243 \pm 0.0118$ \\
\hline Lac. Period & & NS & $\mathrm{NS}$ & NS \\
\hline 1 (4-100 days) & 127 & $12.27 \pm 0.165$ & $-0.578 \pm 0.0010$ & $0.256 \pm 0.0078$ \\
\hline 2 (101-200 days) & 72 & $12.07 \pm 0.217$ & $-0.580 \pm 0.0014$ & $0.261 \pm 0.0102$ \\
\hline 3 (>200 days) & 99 & $12.19 \pm 0.241$ & $-0.577 \pm 0.0015$ & $0.252 \pm 0.0114$ \\
\hline Breed x Season & 298 & NS & NS & NS \\
\hline Breed x Parity & 298 & NS & $*$ & NS \\
\hline Season x Parity & 298 & NS & $*$ & NS \\
\hline Breed x Lac. Period & 298 & NS & NS & NS \\
\hline Overall & 298 & $12.26 \pm 0.093$ & $-0.579 \pm 0.001$ & $0.256 \pm 0.0044$ \\
\hline \multirow{2}{*}{ Factor } & \multirow{2}{*}{$\begin{array}{c}\text { BHBA } \\
(\mathrm{mmol} / \mathrm{L})\end{array}$} & \multirow{2}{*}{$\mathrm{pH}$} & \multicolumn{2}{|r|}{$\log _{10} \mathrm{SCC}$} \\
\hline & & & $\mathrm{n}$ & $(\mathrm{SCC}, \text { cells } / \mathrm{ml})^{\#}$ \\
\hline Breed & NS & NS & & NS \\
\hline RH & $0.284 \pm 0.0138$ & $6.47 \pm 0.0064$ & 66 & $5.417 \pm 0.0173(261,216)$ \\
\hline SIM & $0.269 \pm 0.0093$ & $6.48 \pm 0.0044$ & 133 & $5.401 \pm 0.0118(251,768)$ \\
\hline Season & NS & NS & & $* *$ \\
\hline Winter & $0.290 \pm 0.0138$ & $6.47 \pm 0.0066$ & 100 & $5.495 \pm 0.0168^{\mathrm{Aa}}(312,608)$ \\
\hline Summer & $0.263 \pm 0.0103$ & $6.48 \pm 0.0049$ & 99 & $5.322 \pm 0.016^{\mathrm{Bb}}(209,894)$ \\
\hline Parity & NS & NS & & NS \\
\hline 1 & $0.296 \pm 0.0142$ & $6.48 \pm 0.0068$ & 53 & $5.423 \pm 0.0176(264,850)$ \\
\hline 2 & $0.277 \pm 0.0157$ & $6.47 \pm 0.0075$ & 40 & $5.414 \pm 0.0194(259,418)$ \\
\hline 3 & $0.272 \pm 0.0176$ & $6.47 \pm 0.0084$ & 34 & $5.425 \pm 0.0236(266,073)$ \\
\hline 4 & $0.254 \pm 0.0245$ & $6.47 \pm 0.0117$ & 20 & $5.361 \pm 0.0310(229,615)$ \\
\hline $5+$ & $0.284 \pm 0.0168$ & $6.47 \pm 0.0080$ & 52 & $5.420 \pm 0.0214(263,027)$ \\
\hline Lac. Period & NS & NS & & NS \\
\hline 1 (4-100 days) & $0.273 \pm 0.0111$ & $6.48 \pm 0.0053$ & 95 & $5.413 \pm 0.0145(258,821)$ \\
\hline 2 (101-200 days) & $0.266 \pm 0.0146$ & $6.48 \pm 0.0070$ & 52 & $5.399 \pm 0.0196(250,611)$ \\
\hline 3 (>200 days) & $0.291 \pm 0.0162$ & $6.46 \pm 0.0077$ & 52 & $5.414 \pm 0.0238(259,418)$ \\
\hline Breed x Season & NS & NS & 199 & $* *$ \\
\hline Breed x Parity & NS & NS & 199 & NS \\
\hline Season x Parity & NS & NS & 199 & $* *$ \\
\hline Breed $x$ Lac. Period & NS & NS & 199 & NS \\
\hline Overall & $0.273 \pm 0.0062$ & $6.48 \pm 0.003$ & 199 & $5.406 \pm 0.0108$ \\
\hline
\end{tabular}

RH: Red-Holstein, SIM: Simmental, NS: Not significant, *: Significant for P<0.05, **: Significant for P<0.01, ${ }^{*}$ : Back-transformed SCC value. a,b: The difference between the groups with the same letter is insignificant for $\mathrm{P}<0.05$. A, B: The difference between the groups with the same letter is insignificant for $\mathrm{P}<0.01$.

Other substances found in milk are MUN, OA, BHBA and other traits focused on $\mathrm{FP}$ and $\mathrm{pH}$ averages are given in Table 2. The overall means of MUN, FP, OA, BHBA and $\mathrm{pH}$ are $12.26 \pm 0.093 \mathrm{mg} / \mathrm{dL},-0.579 \pm 0.001^{\circ} \mathrm{C}, 0.256$ $\pm 0.0044 \mathrm{~g} / 100 \mathrm{~g}, 0.273 \pm 0.0062 \mathrm{mmol} / \mathrm{L}$ and $6.48 \pm$ 0.003 , respectively. The effects of all factors on MUN are found to be statistically not significant $(\mathrm{P}>0.05)$. The mean MUN of the RH and SIM breeds were $12.07 \pm 0.200 \mathrm{mg} /$ $\mathrm{dl}$ and $12.28 \pm 0.138 \mathrm{mg} / \mathrm{dl}$, respectively. Considering that
MUN in raw milk is $7-12 \mathrm{mg} / \mathrm{dl}$ in dairy cattle, the average of MUN obtained for RH and SIM breeds were not higher than MUN upper value reported by Anonymous (2019b) and Taytak (2019) for dairy cattle. From here, it can be said that the energy-protein balance of the diet given to the cows in this enterprise is appropriate.

In this study, $\mathrm{FP}, \mathrm{OA}, \mathrm{BHBA}$ and $\mathrm{pH}$ of the milk were also analyzed. For all of these traits, only the breed $\mathrm{x}$ parity and season $\mathrm{x}$ parity interaction effects on FP were 
significant $(\mathrm{P}<0.05)$, the effects of other factors were not significant $(\mathrm{P}>0.05)$. The mean $\mathrm{FP}$ was calculated as -0.577 $\pm 0.0012^{\circ} \mathrm{C}$ and $-0.579 \pm 0.0009^{\circ} \mathrm{C}$, respectively for $\mathrm{RH}$ and SIM breeds. The overall mean of FP obtained in this study $\left(-0.579 \pm 0.001^{\circ} \mathrm{C}\right)$ was lower than the average reported by Yörükoğlu (2019). The averages of FP obtained for RH and SIM breeds in this study were lower than the average of FP reported for normal raw cattle milk, which can be explained as lower the freezing point in the milk (Anonymous, 2019a).

The differences between breeds used in this study in terms of $\mathrm{OA}$ and BHBA in milk are also not significant $(\mathrm{P}>0.05)$. The averages of OA in the milk of RH and SIM breeds were calculated as $0.258 \pm 0.0095 \mathrm{~g} / 100 \mathrm{~g}$ and $0.255 \pm 0.0065 \mathrm{~g} / 100 \mathrm{~g}$, respectively.

BHBA averages of the breeds were $0.284 \pm 0.0138$ mmol / $\mathrm{L}$ and $0.269 \pm 0.0065 \mathrm{mmol} / \mathrm{L}$, respectively. In this study, the BHBA averages in the milk of RH and SIM breeds were higher than those reported by Taytak (2019) who reported MUN values for dairy cattle.

None of the factors had statistically significant effects on $\mathrm{pH}$ of the milk. The $\mathrm{pH}$ averages in $\mathrm{RH}$ and SIM breeds were calculated as $6.74 \pm 0.0064$ and $6.48 \pm 0.0044$, respectively. In this study, $\mathrm{pH}$ average for $\mathrm{RH}$ was found to be quite close to the $\mathrm{pH}$ value $(6.6-6.8)$ that the cattle raw milk should have (Anonymous, 2019b), while pH average for SIM breed was lower than this limit. It can be said that when RH and SIM breeds are considered to be close to one of each other for the means of MCC and SCC, this low $\mathrm{pH}$ value found for SIM breed could be due to the presence of more phosphoric and stearic anions in the milk, because the acidic feature of the fresh milk is reported that $54-59 \%$ is caused by phosphates, $8-15 \%$ is from carbon dioxide, $8 \%$ is from album and $8 \%$ is from citrates (Anonymous, 2019b). In this study, the overall average for $\mathrm{pH}(6.48 \pm 0.003)$ is lower than the value reported by Yörükoğlu (2019).

\section{Somatic cell count (SCC)}

The effects of season $(\mathrm{P}<0.01)$, breed $\mathrm{x}$ season $(\mathrm{P}<0.01)$ and season $\mathrm{x}$ parity $(\mathrm{P}<0.01)$ interaction effects on $\log _{10}$ SCC were statistically significant, and breed, parity, lactation period, breed $\mathrm{x}$ parity and breed $\mathrm{x}$ lactation period interaction effects were not significant $(\mathrm{P}>0.05)$. $\log _{10}$ SCC averages of RH and SIM breeds were $5.417 \pm$ 0.0173 (261216 cells / ml) and $5.401 \pm 0.0118(251768$ cells / $\mathrm{ml})$, respectively.

The mean SCC in the milk samples taken during the winter and summer seasons of cows in the lactation in the enterprise was calculated as $5.495 \pm 0.0168$ (312508 cells / $\mathrm{ml})$ and $5.322 \pm 0.0161$ (209894 cells / $\mathrm{ml})$, respectively, and the difference between the seasons was significant $(\mathrm{P}<0.01)$. Due to the high correlation with mastitis, the level of SCC in the milk samples taken in the summer, or in other words, lower than the winter season, due to the fact that the precipitation in the region is generally intense in the winter and accordingly, it can be said that due to the milk sample taken in the rainy period, the number of animals that caught mastitis were high.

In this study, if the overall mean of SCC (5.406 \pm 0.0108 ) is transformed backwards, 254683 cells / $\mathrm{ml}$ are found and this average is lower than the average reported by Yörükoğlu (2019). The average of SCC (251768 cells / $\mathrm{ml}$ ) obtained for SIM breed was compared with the studies reported in other breeds since there was no previous study on SIM breed in our country. The average of SCC belonging to the SIM breed is lower than the averages of SCC reported for HF breed by Koç (2006; 2007a).

In addition, Koç et al. (2009) reported lower averages in some dairy farms in Aydin than the average found in his study and the overall mean of SCC found in this study is higher than the average of SCC reported by Koç (2007a) for MB and for HF and MB breeds by Koç (2011).

The average of SCC (261216 cells / $\mathrm{ml}$ ) found in this study for RH breed is higher than results of Y1lmaz (2010) for the same breed, Koç (2011) for HF and MB breeds and Koç (2015) for RH. The overall mean found in this study is lower than the averages reported by raw milk quality and influencing factors in some dairy farm in Aydın (Koç et al., 2009) and HF breed reported by Koç (2006), and HF by Koç (2007a).

\section{Conclusion}

This study was focused on milk quality characteristics of RH and SIM breeds preferred as alternatives to HF in Turkey in recent years. There were not much significant differences in milk quality characteristics between the breeds used in this study. It can also be said that both breeds also have low SCC values, which leads to the preference of $\mathrm{RH}$ and / or SIM breeds rather than the HF breed, which is more likely to have diseases such as mastitis. In the farm where this study was carried out, the high performances of SIM and RH breeds in almost all features show that environmental factors such as maintenance-feedinghousing-herd management offered to the animals in the enterprise are also quite good. The breeds showed that this high performance makes them possible because the owner of the farm is a veterinarian and it may also be linked to the availability of a full-time veterinary health technician working in the enterprise. It can be said that the traits such as MCC, OA, BHBA and MUN, which are among the traits in this study, will come out as more features that will be emphasized in the future. In this sense, it can be said that these traits will make important contributions to determine the quality of the milk produced with more practical analysis methods.

\section{References}

Akbulut Ö. 1998. A review for Simmental cattle performance in Turkey. Atatürk Univ. J. Agri. Fac., 29 (1): 43-49.

Anonymous. 2019a. General features of milk. https://acikders. ankara. edu.tr/pluginfile.php/

Anonymous. 2019b. Blood sampling method. http://www.agrilab.com.tr/pdf/

Atasever S, Erdem H, Jonas EM. 2018. Somatic cell count of milk in Holstein cows raised in Turkey conditions: A comparative evaluation. Scientific Papers. Series D. Anim. Sci., Vol. LXI, Number 1: 11-13.

Atasever S, Tóth V, Jonas EM. 2020. Factors affecting mastitis cases and the correlations of somatic cell count with milk production in Holstein cows. Turk J. Agric. - Food Sci. and Tech., 8(1): 171-173.

Dohoo IR, Leslie KE. 1991. Evaluation of changes in somatic cell counts as indicators of new intramammary infections. Prev. Vet. Med., 10(3):225-237. 
Koç A. 2006. Lactation milk yields and somatic cell counts of Holstein-Friesian and Brown-Swiss cattle reared in Aydın province. J. Anim. Prod., 47(2):1-8.

Koç A. 2007a. Daily milk yield, non-fat dry matter content and somatic cell count of Holstein-Friesian and Brown-Swiss cows. Acta Veterinaria-Beograd. 57(5-6):523-535.

Koç A. 2007b. A study on milk fat content, non-fat dry matter content and somatic cell count of Montbeliarde and HolsteinFriesian cows. Proceedings of the Dairy Conference of Turkey: 386-394. 25-27 October, İzmir/Turkey.

Koç A. 2008. Factors influencing daily yield, somatic cell count and non-fat dry matter content of milk. Indian Vet. J. 85:630-632.

Koç A. 2009. A research on milk yield, milk constituents and reproductive performances of Holstein Friesian and Montbeliarde cows (Poster). XVIIth International Congress of FeMeSPRum, Mediterranean Federation of Health and Production of Ruminants" May 27-30, Perugia, Italy.

Koç A, Çelik Ö, Çerçi S. 2009. A research on morning milking milk yield, milk constituents and somatic cell count of Holstein-Friesian and Montbeliarde breeds. (Poster). 6. National Animal Science Conference. Atatürk University, Faculty of Agriculture, Department of Animal Sicence. 24-26 June. Erzurum/Turkey.

Koç A. 2011. A study of the reproductive performance, milk yield, milk constituents, and somatic cell count of HolsteinFriesian and Montbeliarde cows. Turk. J. Vet. Anim. Sci. 2011; 35: 295-302.

Koç A. 2015. Effects of somatic cell count and various environmental factors on milk yield and foremilk constituents of Red-Holstein cows. Tarım Bil. Der., 21 (3): 439-447.

Koç A. 2016. A review on Simmental raising: 1. Simmental raising in the World and in Turkey. Journal of Adnan Menderes University Agricultural Faculty 2016; 13(2): 97 - 102.

Mucha S, Strandberg E. 2011. Genetic analysis of milk urea nitrogen and relationships with yield and fertility across lactation. J. Dairy Sci., 94(11): 5665-5672.
Polanski S, Czaka H, Latocha M. 1992. The effect of some factors on milk fat and protein percentages of Simmental cows at the Brzozow pedigree farm. Roczniki Naukowe Zootechniki: 19(1) 55-65.

SAS. 1999. Statistical analysis system for windows (Release 8.2). SAS Institute's Inc., Raleigh, NC, USA.

Spek JW, Dijkstra J, Bannink A. 2016. Influence of milk urea concentration on fractional urea disappearance rate from milk to blood plasma in dairy cows. J. Dairy Sci., 99(5): 538803888.

Şekerden Ö, Doğrul F, Erdem H. 1999. Blood and milk protein polymorphism and their effects on various production traits in Simmental cows. Turk. J. Vet. Anim. Sci., 23. Supp. 1:87-94.

Taytak M. 2019. Determination of the Relationship between Milk Urea Nitrogen (MUN) and Nutritional levels in Dairy Cows. Department of Animal Nutrition and Nutritional Diseases Master Thesis. Afyon Kocatepe University, Health Science Institutes, Afyon/Turkey.

Vučić V, Arsić A, Gurinović M, Glibetić M. 2012. Oleic acid content in cow's milk and vegetable oils on Serbian market (Conference Paper). CEFood 2012 - Proceedings of 6th Central European Congress on Food2012, Pages 231-2346th Central European Congress on Food, CEFood 2012; Novi Sad; Serbia; 23-26 May 2012; Code111394.

Yilmaz H. 2010. A Research on Milk Yield and Milk Quality Characteristics of Red-Holstein Cows. Master Thesis. Adnan Menderes University, Graduate School of Natural and Applied Sciences. Department of Animal Science, Aydın/Turkey.

Yörükoğlu AB. 2019. Composition and Quality of Cow Milk Coming to Some High Capacity Milk Processing Plants in İzmir and Their Changes According to Season and Region. Master Thesis. Aegean University, Graduate School of Natural and Applied Sciences. Department of Animal Science, İzmir/Turkey. 